MedieKultur | Journal of media and communication research | ISSN 1901-9726

Editorial

\title{
The Politics of Big Data Aesthetics
}

\section{Morten Søndergaard}

MedieKultur 2016, 59, 1-5

\section{Published by SMID | Society of Media researchers In Denmark | www.smid.dk The online version of this text can be found open access at www.mediekultur.dk}

The focus of this special issue is to investigate the relatively new concept of big data aesthetics; as a new concept, it still has no firm definition and is under-theorized. Therefore, the purpose of this special issue is to investigate the theoretical complexes that might help describe and analyse big data aesthetics from different perspectives.

The contributions here each investigate big data representations from their own perspective - conceptualizations of control on the Internet, sensibilities in ubiquitous environments, in art interventions, and in conceptual beauty - and from different theoretical positions - media studies, empirical analysis, art studies, social constructivism, and media aesthetics or post-Kantian phenomenology. This editor hopes that this special issue may lead to more studies of the peculiar encounter between big data and aesthetics.

But a discussion of big data and aesthetics needs a preamble. After all, how can a phenomenon like big data be said to be connected to aesthetics or art at all?

Recent academic debates suggest that big data is a controversial issue involving serious real-life matters such as surveillance, ubiquitous marketing and tracking, the environment, industry and globalization. Big data is also an issue of (mis)representation. Debates on big data involve a certain fear of (remote) control, which is only intensified by the current situation in Syria and all of the Middle East with its discussion of how to keep tabs on the many refugees from the (civil) wars. Big data may be considered a "radically new kind of 'knowledge infrastructure'” (Bollier, 2010: 1), an ensemble of techniques involving the aggregation, computation and analysis of large, complex sets of content that attempt to establish pat- 
terns and connections. However, it may also be seen as a ubiquitous technology with social and cultural implications that are transforming the way we think (Hayles, 2012: 14). As Falk Heinrich points out in his article in this special issue: big data provide big challenges!

One fundamental challenge is our ability to use data freely in an (empirical or speculative) investigation of what is real (and what is not). In "Beyond the Bubble: Three Empirical Reasons for Re-conceptualizing Online Visibility", Anders Koed Madsen argues that "the way 'big data' techniques in digital society are having an impact on the 'real world representations' that meet its citizens" is motivated by how we conceptualize them. Whereas the concept of "the data bubble" makes it difficult to operationalise the interpretation of data outside its source (and control centre - exemplified in Google), the author argues that the concept of the "vision" of data would enable us empirically to move beyond the idealistic representational control of big data.

The question of the "visioning" or "visualization" of data in a distributed environment is explored from a different perspective in "Datamasser og sansemiljøer - Om den performative iscenesættelse af big data". Here, Ulrik Schmidt points out that the aesthetics of big data is being "staged" in the milieus of sensibilities to which we may react. The author investigates the implications of this "aesthetization" of big data for the way we use and operationalise big data between the mere acquisition of information and our immersive sense experience. The author claims that an aesthetic duality is emerging: Big data is staging experiences that oscillate between hard facts and moist perception.

This fundamental issue of how to represent big data as a distributed sensibility pointing at something outside the data itself (and its organisation and mediation) is an essential question that Thomas Bjørnsten also addresses in his article "Big Data Between Audiovisual Displays, Artefacts, and Aesthetic Experience". Bjørnsten argues that "a certain kind of subjectively embodied data mapping" is taking place when big data moves into the realm of installation art. The issue of the perceptual experience of data is linked to the representation of digital artefacts and computational time. The author's main theoretical question is at the centre of any discussion of big data aesthetics (echoing Mark Hansen from the article "Data-Driven Aesthetics", 2013): "whether contemporary technical mediations of time are in fact beyond aesthetics, which is to say, operative at a level and with an autonomy that simply bypasses circuits linking technics and human beings?"

In his article "(Big) Data, Diagram Aesthetics and the Question of Beauty Data", Falk Heinrich argues that visualisations of big data, on one hand, are associated with the Kantian concept of the sublime but, on the other, represent aspects of beauty. As the author states, "the enticing aspect is the unresolved interplay and juxtaposition between artistic figuration and data flux." The author argues that the notion of beauty in and of data visualisation is transforming the epistemological features of aesthetics. In this post-Kantian situation, the beautiful is defined by the author (with inspiration from Deleuze and conceptual art) as "an immediate pleasure of sense perception and the sublime as a pleasure of ideation connected to the imaginable, as dynamic aspects of aesthetic judgments ..." 
If we accept that mediations of big data are bypassing aesthetics, as Mark Hansen speculates, then we are facing some serious problems. The distribution of a sensibility between politics and aesthetics would, for one thing, be impossible. But, perhaps, even more importantly, the empirical reality towards which big data is pointing us as mediated indexes and codes and the visualization of that reality (in all its multi-layered complexity and contextual dependency) would elude the perceptual system completely. But this is not the case! There is, quite simply, too much evidence that the opposite is happening. Here, I think, it would be helpful to distinguish between non-electronic big data and electronic big data. Whereas non-electronic (big) data have been part of statistical and scientific measurements for a couple of centuries, electronic big data is the newest mediation of those measurements. It still draws heavily on non-electronic formats and designs as well as the premises of visually displayed data. The huge difference is the database and all its 'cloudy' variants.

In his seminal study of the effect of the database on our patterns of representation, The Language of New Media (Manovich 2002), Lev Manovich calls for a new way of understanding the database as medium - or, rather, a new way of understanding how we use this new medium as a cognitive reference tool. The language of new media, then, is not to be understood as a new 'scientism' or 'language of computers'; rather, it should be seen as a demarcation of a transformation in the configuration of our cognitive faculties using conceptual metaphors drawn from programming and computer hardware. It is a very human process Manovich describes despite its apparent mask of technology: how may we understand the metaphors of memory and culture when they are based on the database as medium? Computers/technology and culture influence each other, and we may very well discover something new about ourselves and the way we navigate among ideas about our world, Manovich argues. Thus, it becomes a matter of how we represent and map empirical phenomena. Manovich characterises data visualisation as an "anti-sublime ideal" because "data visualization artists aim at precisely the opposite: to map such phenomena into a representation whose scale is comparable to the scales of human perception and cognition" (32).

The electronically-mediated aesthetics of big data also "inherits" all the issues of nonelectronic data but intensified in its "distribution" and political impact.

As Jacques Ranciere points out in The Politics of Aesthetics, aesthetics "denotes neither art theory in general nor a theory that would consign art to its effects on sensibility." Rather,

Aesthetics refers to a specific regime for identifying and reflecting on the arts: a mode of articulation between ways of doing and making, their corresponding forms of visibility, and possible ways of thinking about their relationships... (Ranciere, 2004: 10).

Thus, what is shared in the different positions on big data aesthetics could be seen as a novel form of political subjectivity and an (investigation of ways of representing the) emergent distribution of a data-based sensibility. As Jacques Ranciere also points out (ibid.), the distribution of the sensible lies at the heart of the relationship between politics and aesthetics, and this volume speculates that the electronic medium of that distribution is, in 
fact, that of big data. The articles in this special issue of Mediekultur bear witness to the fact that the matter of big data intensifies the distribution of the sensible and renders representational mechanisms and formats ever more complex.

\section{Open Section}

The open section of this issue contains three articles - all of which are in Danish - outside the topic of big data aesthetics. The first article, "Mellem kontrol og afmagt: Ændrede relationer mellem politikere og journalister på sociale netværkssider" by Lena Kjeldsen, examines the way newspapers use politicians' online activity. In particular, Kjeldsen is concerned with the extent to which patterns of usage identified in previous studies done during elections can also be found in the period between elections. Based on both interviews and quantitative content analysis, the analysis shows both continuity and change in the newspapers' usage and points to how politicians find that, on one hand, they gain more control over their message while, on the other, lose control due platform immediacy and interactivity.

The second article, "Sociale medier og ulovlige netværk i gymnasieskolen" by Jesper Tække and Michael Paulsen, deals with the tension between a teacher-guided learning community and the 'secret networks' in a high school class. In particular, the article focuses on the incongruity between how these secret networks, exemplified here by sharing results and tasks through closed Facebook groups, are perceived: On one hand, teachers describe the activity of these networks as plagiarism and cheating; on the other hand, leading Internet researchers will describe these working methods as progressive, desirable and appropriate to the new digital media environment.

The third and final, article in the open section is "Lydbranding - En systematisering og karakteristik af litteraturen" by Anders Bonde and Nicolai Jørgensgaard Graakjær. Dealing with the field of sound branding, the article aims to demonstrate that far more literature on sound branding exists than hitherto acknowledged. Based on systematically-performed literature searches, the article presents an inductively-developed categorisation of five different types of contributions with the aim of establishing an academic foundation for future sound branding studies by researchers and students. The article highlights the fact that, although the available literature is relatively extensive, a number of lacunae in theory and knowledge still exist because certain questions and activities are ignored or only dealt with in passing, which opens up avenues for future research. 
Editorial: The Politics of Big Data Aesthetics

\section{References}

Bollier, David. (2010). "The Promise and Peril of Big Data." Washington: The Aspen Institute.

Hansen, Mark. (2013, 19 June). Data-Driven Aesthetics. The New York Times, Bits Blog.

(http://bits.blogs.nytimes.com//2013/06/19/data-driven-aesthetics/?_r=0)

Hayles, Katherine. (2012). How We Think. Digital Media and Contemporary Technogenesis. Chicago/London:

The University of Chicago Press.

Manovich, Lev. (2002). The Language of New Media, Cambridge, Mass.: MIT Press.

Ranciere, Jacques. (2004). The Politics of Aesthetics, Paris: Gallimard. 